\title{
FOUR SURVEYS OF LEPROSY IN THE LANGO DISTRICT OF UGANDA
}

\author{
B. P. B. Ellis
}

\section{Introduction}

\author{
(formerly BELRA worker, Uganda)
}

Four leprosy surveys were carried out in the Lango District of Uganda in 1960. At that time the author was a worker of the British Leprosy Relief Association assigned to assist in carrying out the policy of the Ministry of Health in the Northern Province of Uganda. The Lango District lies between $1^{\circ} 45^{\prime}$ and $2^{\circ} 40^{\prime} \mathrm{N}$. and $32^{\circ} 15^{\prime}$ and $33^{\circ} 30^{\prime} \mathrm{E}$. The average altitude of the survey areas is $3,500 \mathrm{ft}$. $(1,076 \mathrm{~m}$.) above sea level. The area is $4,464 \mathrm{sq}$. miles (about $12,080 \mathrm{~km} .{ }^{2}$, plus $595 \mathrm{sq}$. miles (about $563 \mathrm{~km} .{ }^{2}$ ) of open water and swamp. The population at the 1959 census was 354,311 , with a density of 79 persons per sq. mile (about 30 per $1 \mathrm{~km} .{ }^{2}$ ).

\section{Method of Survey}

The survey team consisted of the District Medical Office, Dr. S. M. McKenzie, and Medical Officers Dr. P. N. Williams (for Surveys 1 and 2) and Dr. C. J. Lewthwaite (for Surveys 3 and 4), and 2 Health Inspectors, E.A. (Mr. D. Omole for Surveys 1 and 2, and Mr. L. Ochero for Surveys 3 and 4); and Mr. Ellis.

In order to obtain information on population distribution, the team carried out a domestic census before the sample areas were selected, by permission of the Hon, the District Commissioner. The social structure of the Lango people lends itself to an intimate study of this nature. The Lango District is divided into 7 counties, varying in population from 94,780 to 24,197 . There are sub-counties which vary in population from 3,916 to 15,740 . Sub-counties are further divided into pat ishes, which vary in population from 539 to 2,714 . All chiefs are salaried, but the leadership contains also the unsalaried work leaders or adwong-wan-tics. The male members of the community choose these adwong-wan-tics, who are in charge of 17 to 273 people, and their number in a parish will vary with population density. These leaders have or gain an intimate knowledge of the people, and are invaluable in a domestic census, and their work in a census is regarded as reliable. Their figures agreed to within $3.4 \%$ with the results of the main census carried out shortly afterwards. The team selected the four survey areas at parish level, taking into account the question of the greatest number of people who could be handled in 6 hours by the survey team at the actual survey, and the necessity of confining the investigation to the northèrn part of the district.

The next step was to compile a nominal roll of family groups in each area, and for this purpose the two health inspectors toured the 


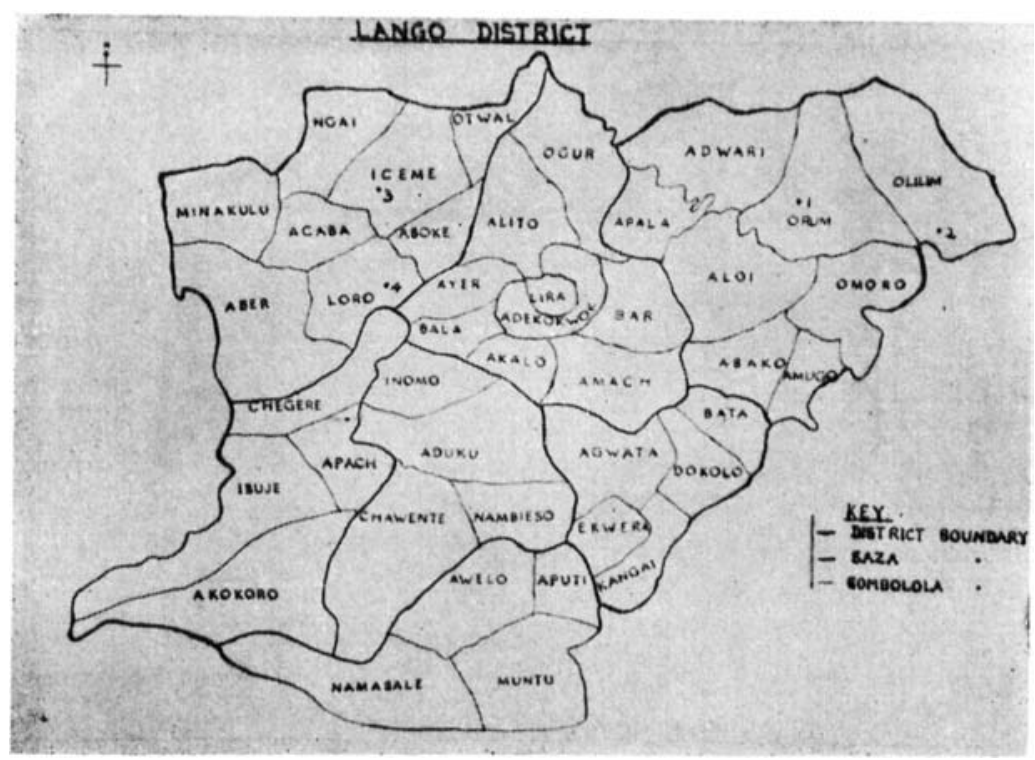

areas in company with the adwong-wan-tics. The nominal roll, once formed, was then checked against tax registers. These preliminary measures excited the curiosity of the people, and this was satisfied, and expected benefits pointed out, at a one-day course at District Headquarters, where chiefs were instructed also on the mechanics of the survey and in a social atmosphere enjoyed rehearsing their parts. The success of this preliminary explanation was shown later by an attendance of the people at the survey of $95.5 \%$. The method of survey was similar to that of J. A. KinNEAR BROWN, specialist leprologist in Uganda, and described by him in the East African Medical Journal, 1956, 33, 7.

The Survey Areas were as follows:

(1) Survey 1 in Moroto County, with a population of 73,495 ; in the sub-county of Orum, with 8,407 people; in the Parish of Ating, with 1,153 people. The population density was 45 per square mile (about 19 per sq. km.).

(2) Survey 2 in Moroto County, in Olilim sub-county with a population of 9,260; in Ogwete Parish with 1,545 people. The population density was 50 per sq. mile (about 19 per sq. km.).

(3) Survey 3 in Oyam County, with a population of 67,194; in Iceme sub-county with a population of 8,398 ; in Omolo Parish, with 949 people. The population density was 53 per sq. mile (about 20 per sq. km.).

(4) Survey 4 in Oyam County, in Loro sub-county with a population of 5,815, in Agulutude Parish with 1,257 people. The population density was 63 per sq. mile (about 26 per sq. km.). 


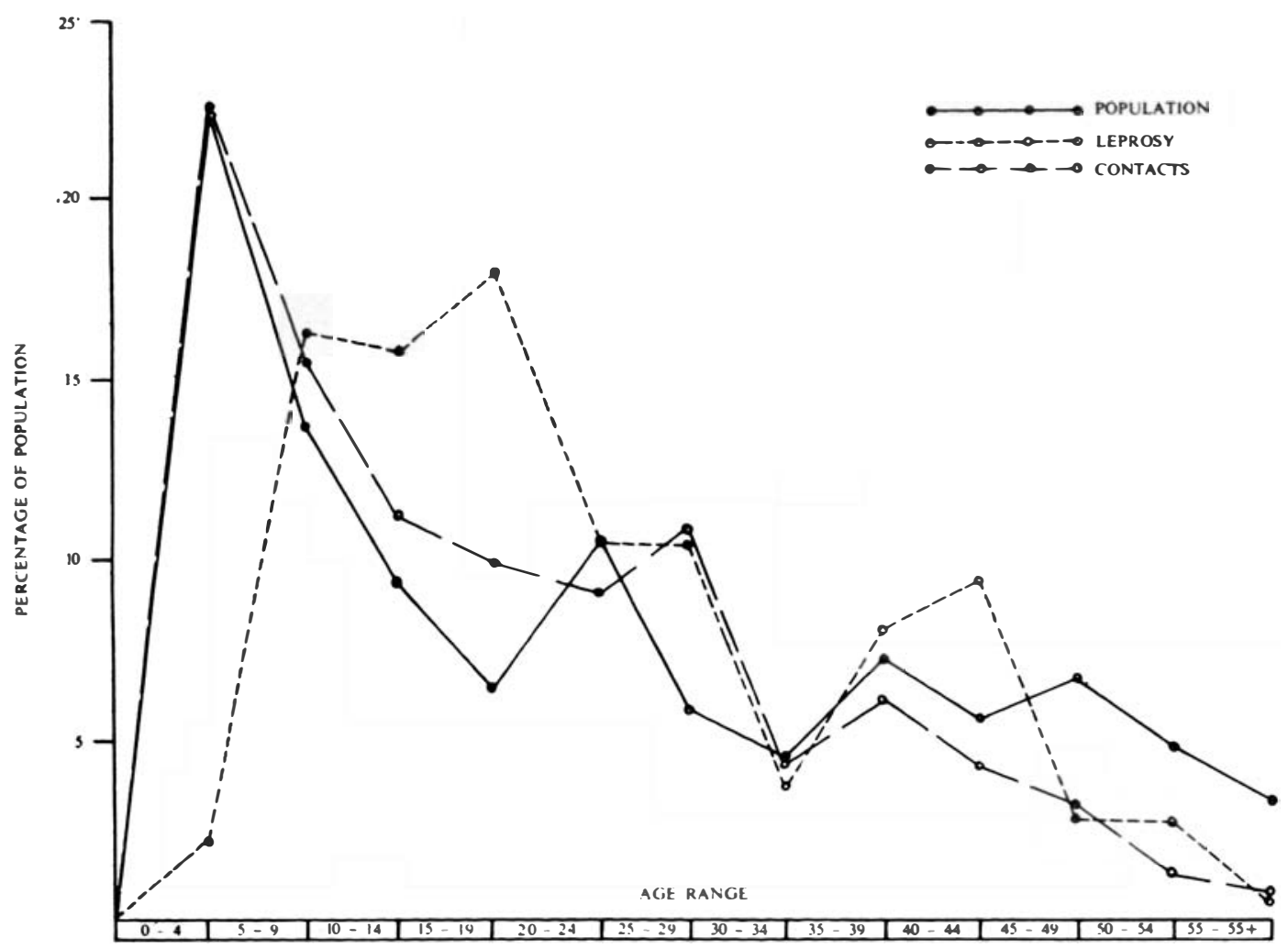

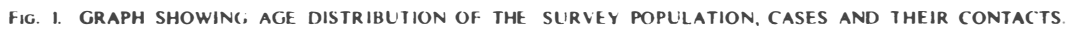





\section{Survey Results}

Follow-up examinations were carried out during the month after the main surveys.

TÁBLE I

The Number of Persons Examined

\begin{tabular}{|c|c|c|c|c|c|c|c|c|c|}
\hline \multirow[t]{2}{*}{$\begin{array}{c}\text { Age } \\
\text { Range }\end{array}$} & \multicolumn{2}{|c|}{$\begin{array}{c}\text { Survey } 1 \\
\text { Ating }\end{array}$} & \multicolumn{2}{|c|}{$\begin{array}{l}\text { Survey } 2 \\
\text { Ogwete }\end{array}$} & \multicolumn{2}{|c|}{$\begin{array}{c}\text { Survey } \\
\text { Omolo }\end{array}$} & \multicolumn{2}{|c|}{$\begin{array}{c}\text { Survey } 4 \\
\text { Agulurude }\end{array}$} & \multirow[t]{2}{*}{ Total } \\
\hline & $M$ & $F$ & $M$ & $F$ & $M$ & $F$ & $M$ & $F$ & \\
\hline $0-4$ & 116 & 131 & 161 & 173 & 95 & 91 & 134 & 148 & 1049 \\
\hline $5-9$ & 90 & 71 & 108 & 86 & 58 & 47 & 97 & 78 & 635 \\
\hline $10-14$ & 57 & 43 & 75 & 75 & 49 & 38 & 58 & 44 & 439 \\
\hline $15-19$ & 32 & 39 & 57 & 37 & 28 & 23 & 37 & 45 & 298 \\
\hline $20-24$ & 46 & 75 & 73 & 77 & 39 & 46 & 50 & 81 & 487 \\
\hline $25-29$ & 32 & 37 & 37 & 44 & 26 & 26 & 33 & 38 & 273 \\
\hline $30-34$ & 17 & 21 & 28 & 58 & 14 & 32 & 18 & 23 & 211 \\
\hline $35-39$ & 34 & 43 & 81 & 36 & 44 & 21 & 47 & 38 & 344 \\
\hline $40-44$ & 29 & 34 & 32 & 49 & 18 & 25 & 34 & 37 & 258 \\
\hline $45-49$ & 47 & 39 & 49 & 35 & 27 & 22 & 52 & 44 & 315 \\
\hline $50-54$ & 26 & 31 & 30 & 32 & 18 & 19 & 28 & 36 & 220 \\
\hline $55-55+$ & 30 & 13 & 36 & 4 & 20 & 3 & 36 & 15 & 157 \\
\hline Total & & & 14 & & & 29 & & & 4686 \\
\hline $\begin{array}{l}\text { Percentage } \\
\text { Attendance }\end{array}$ & 98 & & 95 & & 87. & & 99 & & 95.5 \\
\hline
\end{tabular}

TABLE II

Age, Sex and Type Distribution of Leprosy Cases

The Surveys are grouped together.

\begin{tabular}{|c|c|c|c|c|c|}
\hline \multirow{2}{*}{$\begin{array}{c}\text { Age } \\
\text { Range }\end{array}$} & \multicolumn{2}{|c|}{ Male } & \multicolumn{2}{|c|}{ Female } & \multirow[b]{2}{*}{ Total } \\
\hline & $L$ & $T$ & $L$ & $T$ & \\
\hline $0-4$ & 一 & 2 & - & 1 & 3 \\
\hline $5-9$ & - & 12 & - & 10 & 22 \\
\hline $10-14$ & - & 11 & 2 & 8 & 21 \\
\hline $15-19$ & 2 & 11 & - & 10 & 23 \\
\hline $20-24$ & - & 3 & - & 11 & 14 \\
\hline $25-29$ & 1 & 1 & 2 & 10 & 14 \\
\hline $30-34$ & - & 4 & - & 1 & 5 \\
\hline $35-39$ & 3 & 2 & 3 & 3 & 11 \\
\hline $40-44$ & 3 & 4 & 1 & 5 & 13 \\
\hline $45-49$ & - & 2 & 1 & 1 & 4 \\
\hline $50-54$ & - & 2 & - & 2 & 4 \\
\hline $55-55+$ & - & 1 & - & - & 1 \\
\hline Total & 9 & 55 & 9 & 62 & 135 \\
\hline
\end{tabular}


TABI.E: III

Number of Persons in Close Contact with Cases

\begin{tabular}{|c|c|c|c|c|c|c|c|c|c|}
\hline \multirow[t]{2}{*}{$\begin{array}{c}\text { Age } \\
\text { Range }\end{array}$} & \multicolumn{2}{|c|}{$\begin{array}{c}\text { Survey } 1 \\
\text { Ating }\end{array}$} & \multicolumn{2}{|c|}{$\begin{array}{l}\text { Survey } 2 \\
\text { Ogwete }\end{array}$} & \multicolumn{2}{|c|}{$\begin{array}{c}\text { Survey } 3 \\
\text { Omolo }\end{array}$} & \multicolumn{2}{|c|}{$\begin{array}{l}\text { Survey } 4 \\
\text { Agulurude }\end{array}$} & \multirow[t]{2}{*}{ Total } \\
\hline & $M$ & $F$ & $M$ & $F$ & $M$ & $F$ & $M$ & $F$ & \\
\hline $0-4$ & 12 & 9 & 30 & 43 & 10 & 9 & 13 & 20 & 146 \\
\hline $5-9$ & 10 & 7 & 22 & 27 & 6 & 5 & 17 & 6 & 100 \\
\hline $10-14$ & 12 & 4 & 17 & 10 & 4 & 8 & 11 & 7 & 73 \\
\hline $15-19$ & 3 & 3 & 22 & 16 & 7 & 2 & 4 & 8 & 65 \\
\hline $20-24$ & 4 & 17 & 7 & 11 & 5 & 4 & 4 & 6 & 58 \\
\hline $25-29$ & 7 & 15 & 13 & 24 & 4 & 2 & 1 & 5 & 71 \\
\hline $30-34$ & 6 & 1 & 10 & 5 & 3 & 2 & 1 & 1 & 29 \\
\hline $35-39$ & 7 & 1 & 10 & 8 & 4 & 5 & 2 & 4 & 41 \\
\hline $40-44$ & 2 & 1 & 6 & 1 & - & 4 & 5 & 7 & 26 \\
\hline $45-49$ & - & 2 & 2 & 2 & 5 & 3 & 5 & 4 & 23 \\
\hline $50-54$ & 1 & - & 1 & 1 & 1 & 1 & 2 & 2 & 9 \\
\hline $55-55+$ & - & - & - & - & 2 & - & 1 & 4 & 7 \\
\hline Total & 64 & 60 & 140 & 148 & 51 & 45 & 66 & 74 & 648 \\
\hline $\begin{array}{l}\text { Percentage } \\
\text { of Sample }\end{array}$ & \multicolumn{2}{|c|}{11.24} & \multicolumn{2}{|c|}{20.23} & \multicolumn{2}{|c|}{11.94} & \multicolumn{2}{|c|}{11.45} & 13.61 \\
\hline
\end{tabular}

TABLE IV

The Family Group and Leprosy

\begin{tabular}{rrrrrrrr}
\hline \multicolumn{1}{c}{ Number of families of 26 in number 1 had 1 case of leprosy. } \\
,$"$
\end{tabular}

Thus 783 people in 128 families produced 135 cases of leprosy. 
TABLE V

Summary of the Four Survey's

\begin{tabular}{|c|c|c|c|c|c|c|c|}
\hline \multirow[b]{2}{*}{ Area } & \multirow{2}{*}{$\begin{array}{c}\text { Number } \\
\text { Examined }\end{array}$} & \multirow{2}{*}{$\begin{array}{l}\text { Number } \\
\text { of Cases }\end{array}$} & \multicolumn{2}{|c|}{ Number of Cases } & \multirow{2}{*}{$\begin{array}{l}\text { Incidence } \\
\text { per thou. }\end{array}$} & \multirow{2}{*}{$\begin{array}{c}\text { Leproma } \\
\text { Rate }\end{array}$} & \multirow{2}{*}{$\begin{array}{l}\text { Child } \\
\text { Rate }\end{array}$} \\
\hline & & & Adult & Children & & & \\
\hline Survey 1 & 1133 & 30 & 22 & 8 & 26.4 & $16.6 \%$ & $26.6 \%$ \\
\hline Survey 2 & 1473 & 51 & 29 & 22 & 34.6 & $19.6 \%$ & $43.1 \%$ \\
\hline Survey 3 & 829 & 25 & 18 & 7 & 30.1 & 4. $\%$ & $28 . \%$ \\
\hline Survey 4 & 1251 & 29 & 20 & 9 & 23.1 & $10.3 \%$ & $31.3 \%$ \\
\hline Total & 4686 & 135 & 89 & 46 & 28.8 & $13.3 \%$ & $34.1 \%$ \\
\hline
\end{tabular}

\section{Discussion}

It will be noted that 217 persons $(4.5 \%)$ failed to attend the surveys. The cause of this were death in 8 , permanent change of address from the area 106, and unexplained absence in 103.

Of the leprosy cases diagnosed in the survey, only 17 out of the 135 were undergoing treatment.

Analysis of the age groups of the subjects of the surveys reveals that 2123 persons $(46.5 \%)$ are children of 14 years of age and under, and this group contains $1049(49.4 \%)$ of 4 years of age and under. This distribution resembles the average pattern of the district. Fig. 1 is a graph of the relationship between the age distributions of the survey group and the whole population.

\section{Summary}

In 4 surveys a total of 4686 people were examined for leprosy in the Lango District of Uganda, and 135 cases of leprosy were found. The lepromatous rate reached $19 \%$ in one of the surveys, and in another the child rate reached $34 \%$. The incidence per thousand of leprosy lay between 23 and 34 .

\section{Acknowledgement}

Thanks are tendered to the Chief Medical Officer, Uganda for permission to publish this paper. 